\title{
ZANIKLÉ STŘEDOVĚKÉ MĚSTO SEZIMOVO ÚSTÍ
}

\author{
RUDOLF KRAJÍC
}

\begin{abstract}
Abstrakt: Sezimovo Ústí leži v jižnich Čechách nedaleko Tábora. Jeho středověké dějiny jsou bezprostředně spjaty s počátky husitství. Město bylo založeno před polovinou 13. století. Během své vice než stopadesátileté historie ziskalo podobu vrcholně středověkého poddanského města řemeslnicko-zemédělského charakteru s opevněním, farou, farním kostelem, špitálem, klášterem a výstavnými měštanskými domy kolem náměstí. Bylo vybudováno na pravém břehu řeky Lužnice v prostoru dnešního Sezimova Ústí I a postupně bylo obklopeno třemi predměstími. Město zaniklo za dramatických okolností 30. března roku 1420. Po zániku zůstala plocha města až do počátku 19. století neosídlena. V roce 1828 zde byla založena osada Starý Tábor (Alt Tabor), od roku 1920 znovu přejmenovaná na Sezimovo Ústí. Studie je věnována podobě středověkého města, jak vyplývá z archeologických výzkumů prováděných na lokalitě více než sto let.
\end{abstract}

Klíčová slova: středověk - husitstvi-jižni Čechy-město-předměstí- remesla-archeologie.

\section{The deserted medieval town of Sezimovo Ústí}

Abstract: The town of Sezimovo Ústi is located in southern Bohemia, near Tábor. Its medieval history is closely linked with the beginnings of the Hussite movement. The town was established before the mid-13th century, and in the course of its history spanning over 150 years adopted a form of a high-medieval town owned by the nobility with crafts and farming, fortifications, a parsonage, parish church, hospital, monastery and magnificent burgher houses lining the town square. The town was built on the right bank of the Lužnice river, on the site of present-day Sezimovo Ústi I, and it was progressively encircled by three suburbs. The town ceased to exist under dramatic circumstances on 30 March 1420. After that, it remained deserted until the early 19th century. In 1828 the Starý Tábor (Alt Tabor) settlement was established on the site, renamed to Sezimovo Ústi in 1920. The study is devoted to the form of the medieval town as evidenced by archaeological research conducted on the site for over a hundred years.

Key words: Middle Ages - Hussite movement - southern Bohemia - town - suburb - crafts - archaeology.

\section{Stř̌edověká historie města}

Sezimovo Ústí leží v jižních Čechách nedaleko Tábora. Jeho středověké dějiny jsou bezprostředně spjaty s počátky husitství. Město Ústí založili u soutoku Lužnice s Kozským potokem Vítkovci, nejspíše páni z Hradce. Jednalo se o aktivitu, která souvisela se středověkou urbanizací na jihočeských panstvích šlechty. Protože se nejstarší písemná zpráva o Ústí dochovala k roku 1250 k místnímu klášteru, a protože je známo, že se dominikánský řád usazoval především v rozvíjejících se městech, je $\mathrm{z}$ toho vyvozováno, že město muselo být založeno již před polovinou 13. století.

Nedlouho po založení ohrozilo vývoj obce budování nového městského sídliště na nedaleké táborské ostrožně, jehož iniciátorem byl Přemysl Otakar II. Jedním ze záměrů městského založení na táborském ostrohu měla být panovníkova snaha o omezení narůstající moci vítkovských rodů v jižních Čechách. Tento pokus o založení nového opěrného bodu ve strategicky výhodné poloze při řece Lužnici však zůstal po panovníkově smrti nenaplněn. Nedaleké Ústí se tak mohlo bez výraznější konkurence vyvíjet do podoby regionálního střediska (Richter-Krajíc 2001).

Město bylo vybudováno na pravém břehu řeky Lužnice v prostoru dnešního Sezimova Ústí I. Během své více než stopadesátileté historie získalo podobu vrcholně střredověkého poddanského města řemeslnicko-zemědělského charakteru, využívajícího k provozu i obchodování sít' cest a dalších komunikačních spojů (řeka, přístav na Kozském potoce, přemostění, místní i dálkové suchozemské cesty ad.). Centrem společenského dění bylo téměř do středu města umístěné náměstí, propojené s ostatními částmi obce uliční sítí, k níž byla orientována domovní zástavba. $Z$ významných staveb uvnitř opevněného městského areálu lze jmenovat farní kostel 
s farou, klášter a sídlo majitelů města, kteří byli od konce 13. století uváděni jako páni z Ústí. Městský areál zaujímal plochu přibližně 10 hektarů. Od konce 13. nebo počátku 14. století bylo město opevněno hradební zdí. Na konci 14. století byl v Ústí zř́izen špitál. Základní obdélný půdorys města byl na severozápadní straně rozš́iřen o rozsáhlý trojúhelníkovitý výběžek, který byl vyčleněn pro areál dominikánského kláštera.

Město těžilo nejen z rozvíjející se místní řemeslnické výroby, ale i z výhodné polohy, vyhovující regionálnímu i dálkovému obchodování ve směru od Prahy na jih do Podunají (Richter-Krajíc 2001).

Postupem doby bylo Ústí obklopeno třemi předměstími, jež vytvořila městu žádoucí hospodářsko-provozní zázemí a byla poskytovatelem životního prostoru pro narůstající počet místních obyvatel. Prvním z těchto předměstí byla samostatně opevněná tříhektarová plocha, napojená na severovýchodní okraj města. Na jižní straně obce se nacházelo kolem Kozského potoka druhé předměstí s přístavištěm. Třetí ústecké předměstí bylo umístěno za řeku na levý břeh Lužnice.

Zánik středověkého Ústí bezprostředně souvisí s počátky husitského hnutí na jihu Čech. V Ústí a jeho okolí pobýval Mistr Jan Hus, jehož myšlenky zde i po jeho smrti šírili stoupenci reformního hnutí. V důsledku narůstajícího napětí bylo Ústí na konci února 1420 husity dobyto a obsazeno. Protože se město z vojensko-strategického hlediska nacházelo v nepříliš výhodné poloze, rozhodli se husité přesídlit na nedaleký ostroh nad řekou Lužnicí a Tismenickým potokem, kde založili husitskou obec, nazvanou Hradiště hory Tábor. Aby se Ústí, ležící v bezprostředním dosahu táborského ostrohu, nemohlo stát nebezpečným opěrným bodem nepřátel, bylo zničeno požárem 30. března 1420. Obyvatelstvo - pokud neopustilo město již dříve samo - přešlo nebo bylo převedeno do nedaleké nově založené obce na táborském ostrohu (podrobněji viz RichterKrajíc 2001).

Po zániku zůstala plocha města až do počátku 19. století neosídlena. V roce 1828 zde byla založena osada Starý Tábor (Alt Tabor), která byla v roce 1920 přejmenována na Sezimovo Ústí.

\section{Dějiny archeologického bádání}

Díky tomu, že po zániku středověkého města zůstala jeho převážná část dlouhou dobu neosídlená, byly zde (v dnešním Sezimově Ústí I) relikty bývalé zástavby včetně rozlehlých spáleništ' dobře patrné až do 19. století (obr. 1). To přitahovalo zájmy sběratelů (Bačová 2010, 422-435; Kořalka 1996, 219-232; Krajíc-Richter rkp.) a postupem doby i terénních badatelů, kteří se začali již před více než sto lety cíleně věnovat odkryvům, jak ve vnitřním areálu bývalého města, tak i v jeho bezprostředním okolí (některá z předměstí). Významnou popularizační roli $\mathrm{v}$ připomínání významu středověkého Ústí sehrál již na konci 19. století prof. Martin Kolář (Kolář 1924, 34-68), jehož informace ovlivnily i místního učitele a zájemce o pozůstatky středověkého města Josefa Švehlu. Ten od přelomu 19. a 20. století zasvětil terénnímu výzkumu zaniklého Ústí několik desítek let. Vedle snah o lokalizaci a charakteristiku nejvýznamnějších staveb se věnoval odkryvům mnoha dalších ploch ve městě i na předměstích, což ho dovedlo až k vlastní představě o původní podobě, rozloze a zástavbě středověkého města (výběrově:

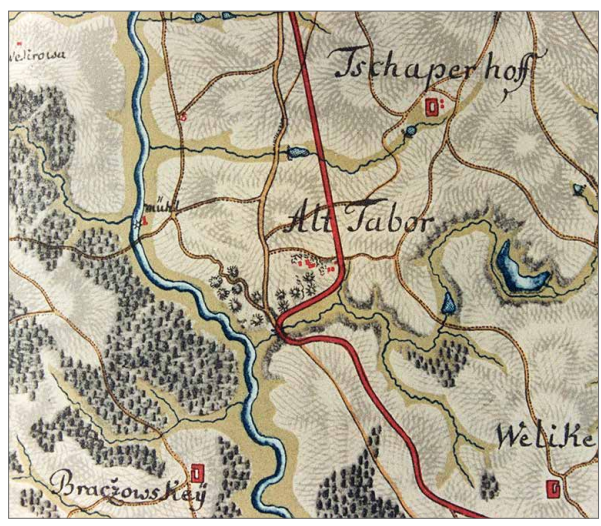

Obr. 1. Lokalita Alt Tábor (zaniklé středověké Sezimovo Ústí) s vyznačením ruin a spáleništ' na výřezu z mapy prvního vojenského mapování z let 1764-1767, část sekce 224.

Abb. 1. Fundstelle Alt Tabor (mittelalterliche Stadtwüstung Sezimovo Ústí) mit Kennzeichnung der Ruinen und Brandflächen auf einem Kartenausschnitt der ersten militärischen Kartierung der Jahre 1764-1767, Sektion 224. 
Švehla 1900; 1907; 1915, 396-400; 1929; 1931, 123-124). Kvůli dramatickým okolnostem zániku a výjimečnému množství v terénu dochovaných středověkých reliktů bylo středověké Ústí označováno jako „české Pompeje“ (např. Švehla 1900). Kromě Josefa Švehly se tématem zaniklého středověkého Ústí zabývali i další regionální zájemci o archeologii (Máška 1946) a historii (napřr. Cikhart 1951, 7-14, 87-93, 128-133; Červenka 1938; PPFL ad.).

Nová etapa zájmu o terénní bádání v Sezimově Ústí byla zahájena v poválečném období, kdy se lokalita dostala do okruhu vědeckého zájmu v souvislosti s programem výzkumu husitských památek (Denkstein 1951, 107-115, zvl. 109-110), a již v roce 1950 byl výzkum zaniklého města zařazen do perspektivního plánu Archeologického ústavu v Praze (Richter-SmetánkaŠpaček 1964, 691). Zásadní posun v poznání středověkého Sezimova Ústí znamenalo zahájení profesionálního terénního výzkumu v roce 1962 na ústeckém levobřežním předměstí. Počáteční záchranná archeologická akce zde postupem doby přerostla $\mathrm{v}$ největší plošný odkryv zaniklého středověkého předměstí na našem území. Výzkum probíhal pod vedením Archeologického ústavu AV ČR v Praze s následnou spoluúčastí Husitského muzea v Táboře a trval více než čtvrtstoletí (výběrově: Hrdlička-Richter-Smetánka 1966, 663-680; Krajíc 1993, 51-56; Richter 1967, 712-717; 1969, 768-782; 1974, 239-257; 1975, 245-258; 1993, 44-51; Richter-Drda 1981，1-21; Richter-Hrdlička 1965, 647, 655-668; Richter-Smetánka-Špaček 1964, 691-715; Richter-Krajíc 2001).

Na místech, kde to bylo možné, byly poznatky o zaniklém Ústí doplňovány terénními výzkumy ve vnitřním městě a v jeho bezprostředním okolí i během posledního půlstoletí (např̀. Huml 1965; 1966, 344-45; Krajíc 1982, 269-277; Krajíc-Richter rkp.). Od 90. let 20. století, kdy došlo v souvislosti se společenskými změnami i k nebývalému stavebnímu rozvoji, jsou formou záchranných archeologických výzkumů Husitského muzea v Táboře zajištovány téměř všechny akce, které ve městě i v jeho okolí (přilehlá zástavba, sídliště, společenské, komerční a inženýrské stavby atd.) zasahují do recentního terénu (výběrově: Krajíc 1996, 76-136; 2008a, 76-81; 2010, 273-282).

Vedle publikací o jednotlivých etapách terénního výzkumu v posledních desetiletích (lit. viz shora) a přehledových studií věnovaných archeologii a historii středověkého Sezimova Ústí (Krajíc-Richter rkp.; Richter 1974, 239-257; 1975, 245-258; 1986, 229-236; 1994, 201-206; Richter-Drda 1981, 1-21; Richter-Krajíc 2001; Šmahel a kol. 1988, 101-116) byly v odborném tisku zveřejněny i vybrané artefakty či rozsáhlejší materiálové soubory (výběrově: Drda-Krajíc 2001, 505-601; Hazlbauer-Chotěbor 1991, 361-383; Hazlbauer-Richter 1990, 416-434, 462-472; Kováŕ 2017, 145-158; Krajíc 1991, 323-342; 2003; 2005, 257-268; 2008; Opravil 1972, 37-46; Reichertová 1965; Richter 1978; Švehla 1901; 1913, 1-15). Převážná část movitých nálezů ze zaniklého středověkého Sezimova Ústí je v současné době deponována v Husitském muzeu v Táboře.

\section{Topografie středověkého Ústí ${ }^{1}$}

Město Ústí bylo vybudováno na soutoku Kozského potoka a řeky Lužnice (obr. 2). Pro vymezení půdorysu středověké obce bylo využito vhodné př́rodní polohy, ohraničené na jihu a jihozápadě vodotečemi, v kombinaci s orientací na světové strany. Město o rozloze kolem deseti hektarů mělo tvar obdélníka s rozšířením pro klášter na severozápadní straně. Severojižní osa dosahovala délky 200-250 m, západovýchodní 450-500 m.

Ne zcela dořešenou dosud zůstává otázka prvního prostorového vymezení a př́ípadného ohrazení města $\mathrm{v}$ době jeho založení nebo těsně po něm. Nelze vyloučit, že se zpočátku jednalo o obec neopevněnou nebo vybavenou jen jednoduchou fortifikací (příkop, palisáda). Opevňovací systém, jehož základem byla až $175 \mathrm{~cm}$ silná kamenná hradební zed' v délce ca $1600 \mathrm{~m}$, totiž

1 Níže uvedené informace jsou - kromě v textu uvedené literatury - podrobněji pojednány také v dosud nedokončeném rukopisu věnovaném topografii středověkého Ústí: Krajíc, R.-Richter M., Sezimovo Ústí - archeologie středověkého poddanského města I. Topografie a dějiny bádání. 


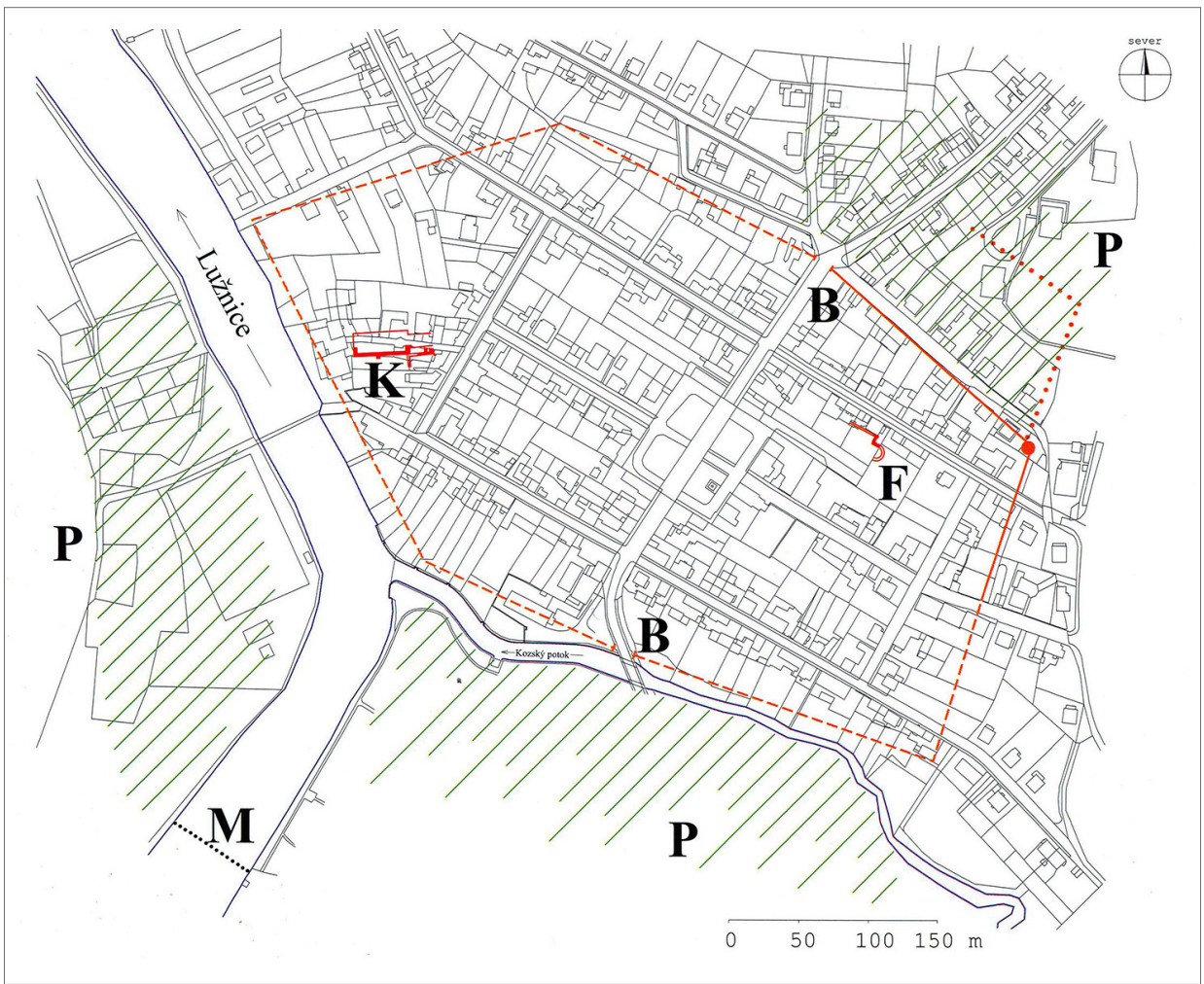

Obr. 2. Promítnutí pravděpodobného plošného rozsahu středověkého města Sezimova Ústí do novodobého plánu zástavby (Sezimovo Ústí I). Plná čára - průběh městského opevnění podle archeologických zjištění; přerušovaná čára - pravděpodobný průběh městského opevnění; tečkovaně - př́íkop na severovýchodní straně města, obklopující připojené předměstí; šikmá čára - stopy po osídlení na předměstích; B - brána; F - farní kostel; K - dominikánský klášter; M - most přes Lužnici; P předměstí. Podle Richter-Krajíc 2001, 6, obr. 1.

Abb. 2. Übertragung der wahrscheinlichen Flächenausdehnung der mittelalterlichen Stadt Sezimovo Ústí in einen neuzeitlichen Bebauungsplan (Sezimovo Ústí I). Durchgezogene Linie - Verlauf der Stadtbefestigung gemäß archäologischen Feststellungen; gestrichelte Linie - wahrscheinlicher Verlauf der Stadtbefestigung; punktierte Linie - die angeschlossene Vorstadt umgebender Graben an der nordöstlichen Seite der Stadt; schräge Linie - Besiedelungsspuren in den Vorstädten; B - Tor; F - Pfarrkirche; K - Dominikanerkloster; M - Brücke über die Lainsitz; P - Vorstadt. Nach Richter-Krajíc 2001, 6, Abb. 1.

vypovídá o opevnění, které mělo Ústí v době svého zániku na počátku 15. století, přičemž lze jeho počátky předpokládat od sklonku 13. do počátku 14. století. Městskému opevnění se podrobněji věnoval Josef Švehla (zvl. 1900; 1907), jehož závěry byly následně doplňovány při záchranných archeologických výzkumech, které se zájmových prostorů dotkly (např. Krajíc 1996, 76-136; či sondážní výzkum Archeologického ústavu AV ČR Praha v roce 1973 v prostoru bašty na severovýchodní straně města). Na základě komparací a analýz více druhů pramenů se předpokládá, že podoba jednotlivých částí městské fortifikace mohla být ovlivněna jak bezpečnostními potřebami, tak i přírodními podmínkami v místech konkrétního terénního průběhu.

Ze stávajících znalostí o ústeckém fortifikačním systému vyplývá, že na východní a severní straně města se před kamennou hradební zdí nacházel příkop o šířce 6-9 $\mathrm{m}$ a hloubce do $3 \mathrm{~m}$, posílený valem s palisádou. V severovýchodním nároží města byla prokázána válcovitá bašta. $\mathrm{Na}$ severovýchodní straně byl vykopán ve vzdálenosti ca $100 \mathrm{~m}$ od města ještě druhý př́kop, který souvisel s ohrazením zde nově vzniklého předměstí (obr. 3). Jihozápadní a jižní strana města, kopírující řečiště Kozského potoka a řeky Lužnice, byly opevněny pouze hradební zdí. 


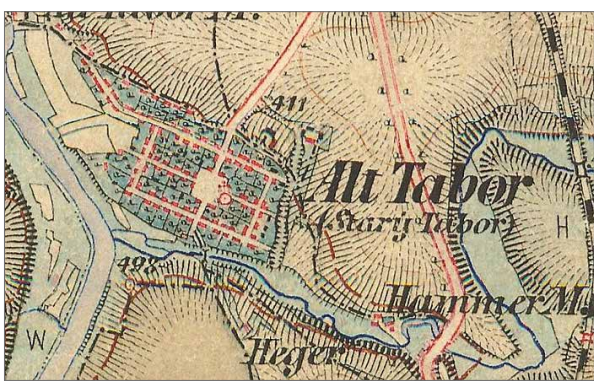

Obr. 3. Půdorys Starého Tábora (Alt Tabor) s rozměřením parcel a uliční sítí na místě zaniklého středověkého Sezimova Ústí. Na východním okraji obce jsou zobrazeny pozůstatky středověkého př́ikopu. Na severovýchodní straně je patrná samostatně vyčleněná plocha, navazující na město a ohraničená př́íkopem. Třetí vojenské mapování z roku 1878, 1 : 25 000, výřez z Landkartenblatt 42532.

Abb. 3. Grundriss von Alt Tabor mit unterteilten Parzellen und Straßennetz an der Stelle der mittelalterlichen Stadtwüstung Sezimovo Ústí. Am Ostrand der Gemeinde sind die Überreste eines mittelalterlichen Grabens dargestellt. An der nordöstlichen Seite ist eine selbständig ausgegliederte Fläche sichtbar, die an die Stadt anschließt und von einem Graben begrenzt wird. Dritte militärische Kartierung von 1878, 1 : 25 000, Ausschnitt aus Landkartenblatt 42532.
Vstup do města zajišt'ovaly dvě hlavní brány (na jižní a severní straně, označované také jako brána Soběslavská a Pražská). Předpokládá se, že propojení města s okolím existovalo i na dalších místech (např. na východní a západní straně, srov. Švehla 1907 ad.). Dálková komunikace vedla kolem jižního okraje řemeslnického předměstí přes lužnický most směrem na Tábor a Prahu. $Z$ této cesty bylo možno odbočit do města. Přes řeku bylo také město propojeno $\mathrm{s}$ levobřežním předměstím (Richter-Krajíc 2001, 135-138).

Centrem města bylo náměstí, o němž se na základě svých terénních zjištění domníval již Josef Švehla, že mělo ve středověku jinou podobu než dnes (obdélníkovité v severní části současného náměstí - Švehla 1900, 27; 1907, 31). Na to, že se tvar, poloha a rozměry náměstí ve středověkém Ústí neshodovaly s jeho půdorysem v novověké obci, ukázaly i některé pozdější záchranné archeologické výzkumy, provedené $\mathrm{v}$ obvodových částech dnešního náměstí (Huml 1965; 1966, 344-345; výzkum Husitského muzea v roce 1998 na rozhraní současného náměstí a Žižkovy ulice - podrobněji in Krajíc 1998). Na základě archeologických výzkumů provedených v historickém centru Ústí (zvl. v jeho jižní části - Krajíc, 1995; 1996, 76-136) lze konstatovat, že na náměstí navazovala geometrická sít' ulic, která více odpovídala orientaci na světové strany než rozměření nové obce $\mathrm{v}$ roce 1828.

Domovní zástavba se $\mathrm{v}$ průběhu více než stopadesátileté existence města proměňovala. Zatímco ve starší etapě - do první poloviny 14. století - nebylo výjimkou, že součástí zástavby jednotlivých městišt' byly i tzv. polozemnice, představovaly nejvyspělejší architekturu v závěrečné etapě osídlení, tj. před rokem 1420, domy na parcelách o šířce 7-12 m, umistované do jejich čela při ulici. Suterénní části domů, jejichž obvodové kamenné stěny měly mocnost kolem $60 \mathrm{~cm}$, byly stavěny na maltu a výjimkou nebyla ani jejich další povrchová úprava, například pomocí vápenné omítky. Některé ze sklepních místností byly odvlhčovány kamennými trativody, umístěnými po obvodu stěn na úroveň podlahy. Přestože v nadzemních částech staveb převládala dřevěnohlinitá konstrukce, dokládají archeologické nálezy i používání stavební keramiky - cihel a formovek (např. výrobní a provozní objekty), keramické střešní krytiny a dlaždic na úpravu podlah. Na parcelách se nacházely hospodářské př́ístavky, studny, pece ad. (Krajíc 1995; 1996, 76-136; 2007; 2008a, 76-81; 2009; 2010, 273-282; Krajíc-Richter rkp.).

Z významných staveb lze vedle sídelní rezidence pánů z Ústí jmenovat klášter, špitál, farní kostel se hřbitovem, nedaleko něho faru se školou, kupecký či nákladnický dům se sklady v jižní části města, mlýn o pěti kolech na předměstí, prŕístav u ústí Kozského potoka do Lužnice ad.

Jako problematické se s odstupem více než jednoho století od provedených prvních terénních odkryvů zdá určení místa, rozlohy a stavební podoby domu pánů z Ústí, které uvedl do literatury Josef Švehla. Ten se domníval, že se rezidence ústeckých Vítkovců nacházela na zahradě u někdejší fary a na přilehlém pozemku (čp. 155 a ppč. 524), přičemž odkazoval na jím objevené relikty zástavby s množstvím „pozoruhodných“ nálezů (např. dýka, ostruhy, kostěné střenky nožů vykládané stříbrem, dlaždice s plastickou výzdobou apod. - Švehla 1900, 17n.). Přestože podobná zjištění o objevech ,pevných zdi“ a výjimečných nálezech učinil J. Švehla 
i v okolí, považoval shora uvedené místo za panský dům, který charakterizoval jako patrovou budovu o poměrně silných zdech krytou prejzy (Švehla 1900).

Severozápadní část městského areálu zaujal klášter, umístěný k pravému břehu řeky Lužnice na okraj obce, kde na jeho vnějším obvodu probíhalo městské opevnění (obr. 2). Atypické umístění trojúhelníkovitého areálu kláštera vně základní obdélné půdorysné dispozice města vyvolává úvahy, zda mohl být klášter založen současně s městem nebo až po určité době jeho prvotní konsolidace (Krajíc-Richter rkp.). Nejstarší písemnou zprávu vztahovanou k ústeckému klášteru obsahují akta generální kapituly dominikánského řádu, jež v roce 1250 vyslovila souhlas se zasvěcením kostela zdejšího konventu zakladateli řehole sv. Dominikovi (Beránek 1998, 5; Šmahel a kol. 1988, 101). Životaschopnost zdejší komunity i rychlý stavební rozvoj $\mathrm{v}$ ústeckém klášterním areálu naznačují další nečetné dochované zprávy. Jednou z nich je informace generální kapituly dominikánů z roku 1256 o založení nového konventu, jež je vztahována k Sezimovu Ústí (Drda-Tecl 1978, 757, pozn. 64). Protože se již v roce 1275 stalo Ústí hostitelským místem provinční kapituly, je zřejmé, že výstavba místního konventu musela významně pokročit (Šmahel a kol. 1988, 101-102, pozn. 72; Šnoblová 2011). O důležitém postavení i ekonomické síle místního kláštera si lze učinit představu z testamentu ze 4. června 1262, v němž za předchozí půjčku ústecké dominikány odškodnil Vok z Rožmberka. Dobré vztahy mezi Vítkovci a místní klášterní komunitou se odrážely i v průběžné finanční podpoře místa, které bylo postupem doby považováno za rodovou fundaci a kostel sv. Dominika s kaplí sv. Petra za rodové mauzoleum spojené s majiteli města - pány z Ústí. Klášter o dvanáctičlenné komunitě bohatl i díky darům a odkazům okolní šlechty, což mu spolu s dalšími aktivitami umožňovalo stavebně se rozvíjet, provozovat rozlehlý areál i zř́idit klášterní školu v čele s řádovým lektorem (Šmahel a kol. 1988, 101-105).

Rekonstrukce původní podoby ústeckého kláštera je značně ztížena téměř kompletním rozebráním nadpovrchových reliktů a ruin v době po znovuzaložení obce v 19. století a také tím, že většina odkryvů, z jejichž popisů lze čerpat alespoň základní fakta, probíhala před více než sto lety (Máška 1946; Švehla 1900; 1907; 1913, 1-15; 1930, 1-9) za nejednoduchých osobních vztahů a s pracovními i dokumentační limity danými dobou „zkoumáni““ (Šmahel a kol. 1988, 107; podrobněji Krajíc-Richter rkp.). V důsledku toho byla většina terénních zjištění i movitých nálezů popisována nebo zakreslována bez podrobnějších stratigrafických rozlišování či přesnějších chronologických charakteristik přesto, že je z více než stopadesátileté doby trvání kláštera a z jeho činností zř̌ejmé, že se vývoj a proměny areálu v čase musely projevit i v jeho architektuře, zástavbě a způsobech využivání přilehlých ploch. I přes pokusy podrobně analyzovat informace dochované k terénním zásahům a odkryvům z 19. a počátku 20. století, komparovat je a pokusit se v nich vysledovat obecněji platná fakta o poloze a podobě klášterních staveb, kvůli často odlišným či málo konkrétním a dnes z větší části neverifikovatelným popisům² ${ }^{2}$ lze vyvodit závěry o zástavbě a využívání jednotlivých ploch ústeckého kláštera jen v rámcových obrysech.

Klášter je rekonstruován jako ohrazený areál s kostelem sv. Dominika a druhou sakrální stavbou na východním okraji (kaple sv. Petra), s klauzurou jižně od kostela, další zástavbou podél a patrně i pod dnešní ulicí Prokopa Holého a s hospodářskými objekty na západní straně. Severně od kostela se mohly rozléhat klášterní zahrady.

K nejvýznamnějším terénním zjištěním z konce 19. století patřily odkryvy F. Mášky v okolí Klášterní ulice (Máška 1946), jež jsou spojovány s pozůstatky klášterního kostela (části jižního obvodového zdiva lodi a presbytáře) a dalších jižně k němu přilehlých staveb. ${ }^{3}$ Odkrytá zed' lodi měla tloušt'ku až $165 \mathrm{~cm}$ a (přibližně) v západovýchodním směru dosahovala délky kolem $35 \mathrm{~m}$. Na západním konci se zachovalo její pravoúhlé zalomení k severu v délce 3-4 m (dále byla již vylámána a odstraněna). Šíŕka lodi se pohybovala kolem $15 \mathrm{~m}$. Presbytár̆ dosahoval

2 Jedná se především o zprávy dvou hlavních autorů F. Mášky a J. Švehly, přičemž zápisy a kresby F. Mášky se zdají př̌esnější a podrobnější (Krajíc-Richter rkp.).

$3 \mathrm{~K}$ problematice přesných poloh jednotlivých klášterních objektů a staveb i jejich rozměrů uváděných F. Máškou a J. Švehlou, stejně jako k provozně funkčním interpretacím uvedenými autory zkoumaných či popisovaných nálezů podrobněji Krajíc-Richter rkp. 
v západovýchodní ose minimálně 15-16metrové délky, k níž je nutno připočítat ještě rozměr východního (patrně polygonálního) uzavření. Při oprávněně předpokládaném odsazení vítězného oblouku ca 2,5-3 m od nároží lodi se mohla šíŕka presbyteria pohybovat kolem $9 \mathrm{~m}^{4}$

Na vnější straně jižní obvodové stěny kostelní lodi objevil F. Máška kromě jiného i torza zdí s kolmým napojením (severojižní orientace), jež odkazují na další klášterní zástavbu, navazující jižním směrem na kostel. Zdivo napojené na jižní stranu presbytáře kostela přísluší patrně sakristii. Protože byly nedaleko objeveny dvě hrobky a zdobené náhrobní kameny, nelze vyloučit, že se v těchto místech nacházela kaple sv. Petra, která sloužila jako rodové mauzoleum majitelů města.

Na několika místech klášterního areálu byly při výzkumech na konci 19. a počátku 20. století nalezeny relikty hospodářských či provozních staveb a ve větším počtu také lidské kostry (Máška 1946; Švehla 1900; 1907; 1930, 1-9). Pohřbívání v ústeckém klášteře není v rozporu ani s životem a potřebami místní komunity, ani s písemnými prameny, které k počátku 15. století zmiňují, že místní faráři nemají bránit dominikánům ve zpovědích a pohřbívání věřících (Krajíc-Richter rkp.).

Uvedené objevy, jež byly v prostoru bývalého kláštera učiněny před sto lety, se staly východiskem pro shora uvedené souhrnné informace o areálu ústeckého kláštera, podobě kostela a stavbách i dalších nálezech $\mathrm{v}$ jeho okolí. K nim přibyly ve druhé polovině 20 . století jednotlivosti (Huml 1965), které byly v posledních letech doplněny o nové poznatky získané v roce 2016 při nových dokumentačních a prospekčních aktivitách na ploše bývalého kláštera a v roce 2019 při záchranném archeologickém výzkumu táborského muzea v ústecké Klášterní ulici.

V roce 2016 vznikl podrobný výškopisný plán klášterního areálu a na dostupných místech bylo provedeno měření georadarem. Naměřené hodnoty byly zaneseny do mapy včetně některých starších podkladů. Výsledkem se stalo interpretační půdorysné schéma kláštera $\mathrm{v}$ době zániku středověkého Ústí (Břicháček-Šindelář 2018, 68, 71, obr. 3). Plán obsahuje návrh podoby klášterního kostela sv. Dominika a upřesňuje jeho polohu v rámci současné zástavby. Dále zobrazuje klauzuru napojenou k jižní stěně lodi kostela a stavbu jižně připojenou na vnější stranu presbyteria. Protože je kostel navržen jako trojlodí s dlouhým polygonálně ukončeným presbyteriem, je připojen i komentář odkazující na podobné stavební řádové tradice, a tudíž i možné inspirace pro výstavbu ústeckého klášterního kostela (Břicháček-Šindelář 2018, 71).

Množství nových poznatků přinesl záchranný archeologický výzkum táborského muzea, který byl v roce 2019 prováděn v souvislosti s budováním inženýrských sítí v Klášterní ulici. Přestože bylo známo, že relikty zaniklých klášterních staveb byly v těchto místech dlouhodobě vylamovány pro nové stavební využití, a tudíž předpoklad o možném rozsáhlejším zachování klášterních objektů pod odkrývanou částí Klášterní ulice nebyl př́liš optimistický, přinesl výzkum překvapivé informace zásadně doplňující stávající poznání ústeckého kláštera a v některých př́ípadech i s širším dosahem do oblasti středověkého urbanismu a chronologického vývoje lokality mezi 13. a počátkem 15 . století. Vedle torz středověké zděné architektury s mnohými konstrukčními a provozními detaily bylo objeveno i několik hrobů a dalších zahloubených objektů. Za cenné lze považovat i relativně dobře zachované původní stratigrafie, což vše dohromady nabízí možnost, že vyhodnocením získaných poznatků dojde k podstatnému doplnění dosavadních znalostí o podobě ústeckého kláštera, o jeho stavebních proměnách i o jeho provozu $\mathrm{v}$ průběhu více než stopadesátileté doby jeho existence.

Na nejvyšším místě ve městě stál již ve 13. století farní kostel se hřbitovem a farou (obr. 2). Obvodové zdi kostela byly v terénu patrné ještě v 19. století. Z částečného terénního odkryvu provedeného v roce $1948^{5}$ odvozujeme, že ústecký farní kostel byl trojlodní stavbou o celkové délce $36 \mathrm{~m}$, pravděpodobné šiřce lodi $22 \mathrm{~m}$, s polygonálním presbytářem o délce $9 \mathrm{~m}$ a šířce $8 \mathrm{~m}$. V prodloužení severní boční lodi kostela směrem severně od kněžiště se patrně nacházela

4 Na základě analýzy dostupných pramenů a dochované dokumentace i zápisů a publikací obou shora uvedených badatelů uvažoval M. Richter o tom, že by kostel rozměrově nejspíše odpovídal jednolodní stavbě s polygonálně uzavřeným presbyteriem (Krajíc-Richter rkp.).

5 Výzkum prováděl místní lékař MUDr. E. Fiala ve spolupráci s F. Lískovcem, který zastupoval Jihočeskou společnost pro zachování husitských památek; ta také hradila mzdy dělníků. K popisu a interpretaci reliktů, odkrytých v roce 1948, včetně diskuse o podobě a rozměrech původního kostela viz podrobněji Miroslav Richter in Krajíc-Richter rkp. 
sakristie. Při kostele pracovalo pět duchovních, kteří měli od roku 1388 na starosti i špitál a farní školu. Z informací místních obyvatel i poznatků Josefa Švehly a F. Mášky vyplývá, že se na rozlehlé ploše obklopující kostel nacházel hřbitov (Máška 1946; Švehla 1907, 31). Jeho část severně od kostela byla detekována také v roce 1947 (PPFL) a v roce 1996 bylo při záchranném archeologickém výzkumu táborského muzea zjištěno, že tímto směrem zasahuje hřbitov až do ulice Hromádkovy.

Nejednotné informace o poloze ústecké fary uváděli všichni zájemci, kteří se podrobnější topografií středověkého Ústí zabývali. Zatímco Josef Švehla se soustředil na prostor u čp. 51 (Švehla 1900, 26; 1907, 31; jinde na zahrádku u čp. 67 - Švehla 1928, 122; 1930a, 89), nevylučovali další badatelé možnost, že se bohatá fara s městskou farní školou, obydlím správce i kantorů a př́slušným hospodářským zázemím mohla nacházet severně za hřbitovem u čp. 4 nebo čp. 5 (Máška 1946, 58; PPFL, inv. č. 120, 19).

Obdobně problematická, stejně jako v prŕípadě fary, je i přesná lokalizace ústeckého špitálu s kaplí sv. Alžběty. Ten byl založen 25. dubna 1388 bratry Sezimou, Ondřejem, Hynkem a Janem z Ústí, kteří tak realizovali nadání svého strýce Sezimy z Ústí, aby zde bylo pečováno o osm chudých. Od roku 1396 se tento počet zvýšil na devět (Sedláček 1933, 137; Cikhart 1951, 12). Do roku 1420 se zde vystřídalo šest správců. Po tomto roce byly špitál i jeho nadání přeneseny na Hradiště hory Tábor (Švehla 1907, 8-9; přejal Cikhart 1951, 12). Přestože se většina badatelů zabývajících se polohou a podobou ústeckého špitálu shodovala v jeho umístění do jižní části města, liší se jejich identifikace místa natolik, že dnes nelze přesné místo určit. Zatímco Martin Kolář uvažoval na základě jedné z dochovaných písemných zmínek bud' o poloze v městských hradbách na pravém břehu Kozského potoka nebo o poloze za hradbami na levém břehu potoka (Kolář 1924, 36), uváděl Josef Švehla nejprve domy čp. 24 a čp. 25 v dnešní Vaníčkově ulici (Švehla 1907, 9, 32) a později prostor v dnešní Bydlinského ulici mezi domy čp. 18 a 188 (Švehla 1931, 124). ${ }^{6}$ F. Máška se domníval, že narazil na zbytky špitálu při svých odkryvech na levém břehu Kozského potoka (Máška 1946, 43), i když na jiném místě svých vzpomínek uvádí i možnost čp. 22 (Máška 1946, 57).

\section{3 Ústecká předměstí}

Postupem doby obklopila město tři předměstí, která tvořila jeho hospodářsko-provozní zázemí a byla poskytovatelem životního prostoru pro narůstající počet místních obyvatel.

Prvním z nich byla samostatně opevněná tříhektarová plocha napojená na severovýchodní okraj města (obr. 2, 3). Významem předměstí se z hlediska urbanistického vývoje a sídelních proměn stř̌edověkého Ústí během jeho stopadesátileté doby existence a ve vazbě na regionální společensko-politické události naposledy zabýval Miroslav Richter. Ten na základě analýz písemných pramenů, topografie města (zvláště s ohledem na mimo městské hradby vyčleněnou samostatnou sídelní jednotku s vlastním opevněním), několika málo dochovaných terénních informací o středověkém osídlení vně severovýchodního obvodu města, ale i díky detailní znalosti sídelních poměrů na levobřežním předměstí dospěl $\mathrm{k}$ závěrům, že by ústecké předměstí označované v písemných pramenech jako „Nové Město“ - dlouhodobou tradicí spojované s předměstím na levém břehu Lužnice - mohlo ve skutečnosti být toto $\mathrm{k}$ městu přičleněné a samostatně opevněné předměstí na severovýchodním okraji města (Krajíc-Richter rkp.). V souvislosti s uvedenou interpretací je možno upozornit také na výhodnou polohu předměstí před severní městskou branou; na jeho půdorysnou podobu, tvarově a orientací blízkou městu (téměř obdélník s delší osou souběžnou s městem); na př́kop, který je na východní straně pokračováním východního městského př́ikopu (obr. 2) a na severní straně probíhá paralelně s městskou hradbou, či na zajímavý fortifikační prvek (baštu) umístěný do severovýchodního rohu městského opevnění na rozhraní města a předměstí.

6 Relikty středověké zástavby na uvedeném místě se zabýval i František Lískovec (PPFL, kart. 3, sešit XXI, s. 32-33, 37-38, 87, 153, HM Tábor, inv. č. 165). Místo bylo dotčeno také archeologickým výzkumem táborského muzea v letech 1990-1991 (Krajíc 1996, 76-136). 
O tom, že se jak v okolí tohoto předměstí, tak i v širším předpolí města severně až severovýchodně od něho mohla lokálně vyskytovat místa využívaná i k nezemědělským činnostem, vypovídají archeologická zjištění z posledních desetiletí. K nim lze v tomto prostoru počítat například objev hrnčířské dílny s pracovním zázemím z tzv. zánikového horizontu Sezimova Ústí (obr. 4; Krajíc 1982, 269-277) či podobné výrobní a sídelně-provozní objekty objevené i na místech vzdálenějších od městských hradeb při výstavbě nových obchodních center ad. na jižním okraji Tábora (např. Krajíc 2004; 2007-2008). Jednalo se o středověké kulturní vrstvy, kủlové jámy, rozměrnější jámy různých tvarů a výrobně-provozní objekty, jež lze z hlediska sídelně-provozního a prostorového vztáhnout k širšímu zázemí stř̌edověkého Sezimova Ústí.

Na jižní straně města se nacházelo na soutoku Kozského potoka a řeky Lužnice druhé předměstí (obr. 2). Kromě toho, že zde bylo možno díky přemostění potoka vstoupit do města od jihu přes Soběslavskou bránu, se zde - v oblouku potoka u budovy dnešního městského úřadu - měla nacházet široká zátoka, kam Josef Švehla situoval př́staviště (Švehla 1907, 34). I přes důležité zprávy o existenci středověkého osídlení na obou březích potoka, jež zaznamenali od konce 19. století až do 30. let 20. století regionální amatérští badatelé, lze z jejich informací vyvodit o charakteru zástavby a plošném rozsahu předměstí jen základní informace (stopy po osídlení, odkryv sklepa, nálezy středověké keramiky apod. - Máška 1946, 43 a 57; Švehla 1900, 21; podrobněji Krajíc-Richter rkp.). Vedle blíže nepopsaných sdělení o domech obchodníků (Švehla 1907, 34) je otázkou, zda lze s tímto jižním ústeckým předměstím spojovat i informace o místním špitálu, mlýnu a lázních (podrobněji Krajíc-Richter rkp.).

Třetí ústecké předměstí bylo umístěno za řeku na levý břeh Lužnice (obr. 5). Na rozdíl od předchozích dvou, kde bylo možno provádět archeologické odkryvy jen v omezené míře, byl na levobřežním předměstí v letech 1962-1988 realizován terénní výzkum, který během let přerostl ze záchranné akce do plošně nejrozsáhlejšího archeologického výzkumu středověkého předměstí

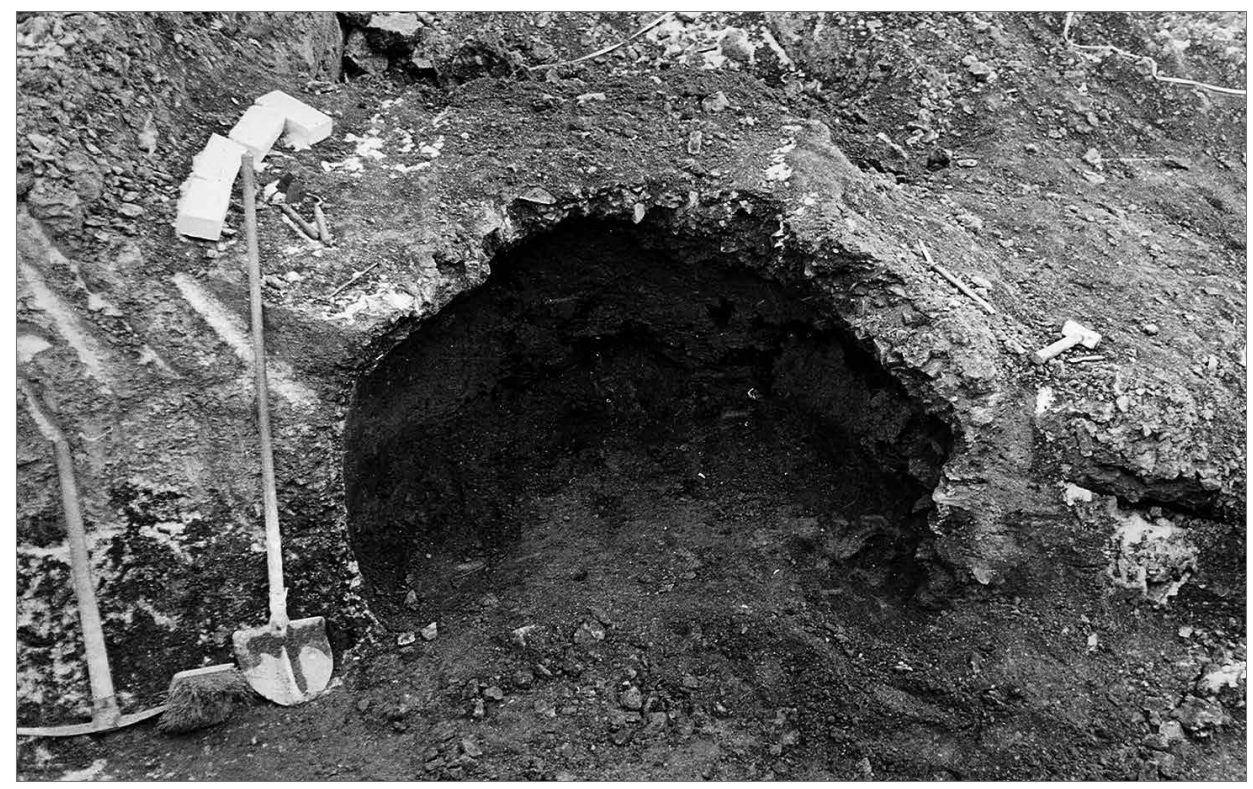

Obr. 4. Hrnčířská pec z tzv. zánikového horizontu středověkého Sezimova Ústí, objevená v 80. letech 20. století na táborském Sídlišti nad Lužnicí v místě, jež původně příslušelo k severovýchodnímu předpolí stř̌edověkého města Sezimova Ústí. Foto R. Krajíc. Abb. 4. Töpferofen aus dem sog. Untergangshorizont des mittelalterlichen Sezimovo Ústí, der in den achtziger Jahren des 20. Jahrhunderts in einer Taborschen Siedlung oberhalb der Lainsitz an einer Stelle entdeckt wurde, die ursprünglich zum nordöstlichen Vorfeld der mittelalterlichen Stadt Sezimovo Ústí gehörte. Foto R. Krajíc. 


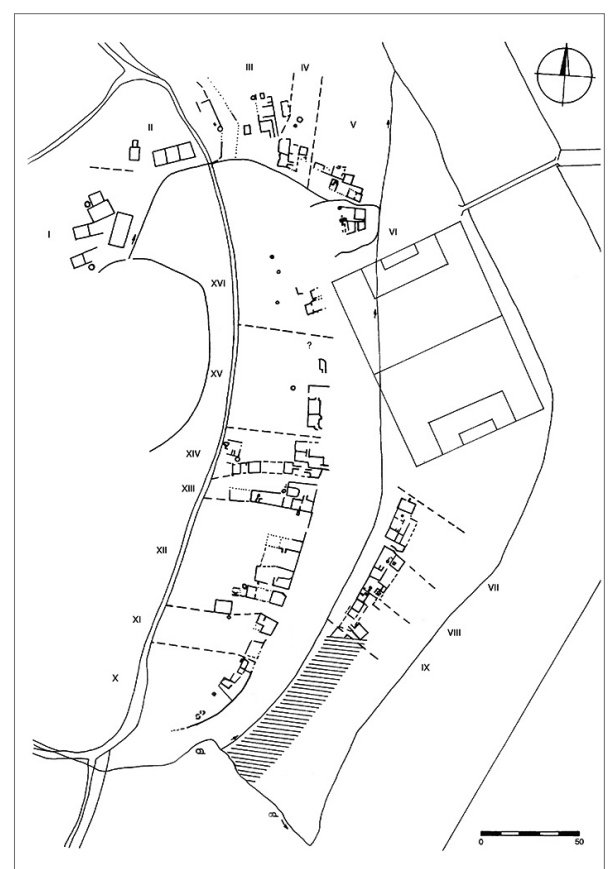

Obr. 5. Ústecké levobřežní řemeslnické předměstí v době zániku stř̌edověkého města v roce $1420 \mathrm{~s}$ označením archeologicky zkoumaných usedlostí (I-XVI) a parcelací (čárkovaně). Rozsah osídlení v archeologicky neodkryté jihovýchodní části předměstí naznačil geofyzikální průzkum (šikmo čárkovaně). Podle Richter-Krajíc 2001, 145, obr. 179.

Abb. 5. Linksufrige Handwerkervorstadt von Ústí zur Zeit des Untergangs der mittelalterlichen Stadt im Jahr 1420 mit Kennzeichnung der archäologisch untersuchten Anwesen (I-XVI) und Parzellierung (gestrichelt). Die Ausdehnung der Besiedelung im archäologisch nicht freigelegten südöstlichen Teil der Vorstadt wird auf Grundlage einer geophysikalischen Untersuchung angedeutet (schräg gestrichelt). Nach Richter-Krajíc 2001, 145, Abb. 179. na našem území. Díky tomu lze toto předměstí i podrobněji charakterizovat.?

Sídliště zaujalo na říčním břehu, protilehlém soutoku Lužnice s Kozským potokem, širokou nivu pozvolna se zvedající směrem od řeky k západnímu př́krému svahu. Plocha předměstí byla na jihu a severu ohraničena dvěma potoky protékajícími zhruba v západovýchodním směru, Lužnicí na východní straně a svahem tzv. Pracovského kopce na straně západní (obr. 6). Původní sídelní osu na severním okraji předměstí tvořil potok, který byl v průběhu 14. století nahrazen o několik metrů vedle vedenou umělou vodotečí, která vytékala z rozměrné vodní nádrže vybudované na západním okraji lokality. $\mathrm{K}$ potoku bylo v závěrečné sídelní fázi ústeckého osídlení umístěno šest řemeslnických usedlostí. V severojižním směru protékal středem sídliště další potok, $\mathrm{k}$ němuž byla $\mathrm{v}$ nejmladší etapě osídlení z obou stran orientována převážná část městišt’ (prozkoumáno 10). Obdobně jako u severního potoka byl i v tomto případě prokázán ve 14. století posun této umělé vodoteče o několik metrů od staršího koryta (Richter-Krajíc 2001, 127-132).

Zdokonalování vodohospodářského i komunikačního systému odpovídalo stavebním a provozním proměnám sídliště $\mathrm{v}$ čase. Jeho počátky spadají do 13. století a lze je spojovat se založením města. Je pravděpodobné, že na výběr polohy měla vliv vedle přírodních podmínek a snadné dosažitelnosti města i dálková komunikace probíhající jižně kolem předměstí. V průběhu 13. století zaujalo osíd-

lení téměř celou levobřežní nivu $\mathrm{v}$ ohybu Lužnice, přičemž v mladší etapě naznačují některé ze zkoumaných sídlištních situací možnost pravidelnějšího rozložení zástavby. ${ }^{8} \mathrm{Je}$ otázkou, zda zjištěný velkoplošný rozsah a zdokonalený charakter zástavby předměstí v poslední čtvrtině 13. století neodráží historické události související s příchodem nových obyvatel do Ústí z nedalekého Hradiště právě v tomto období (Richter-Krajíc 2001, 149). Vedle zemědělství a rybářství lze už $\mathrm{v}$ této etapě osídlení předpokládat pracovní zaměření některých místních obyvatel na řemeslnickou výrobu (např. kovář, kovolitec, hrnčíř, švec a patrně i koželuh; tamtéž).

Na základě terénních archeologických zjištění je zřejmé, že i když sídliště ještě na počátku dalšího století nevykazovalo v charakteru zástavby výrazné odlišnosti od předchozího období, došlo v průběhu 14. století $\mathrm{k}$ stavebně-provozním proměnám, $\mathrm{v}$ jejichž důsledku získalo charakter pravidelně rozčleněné a zastavěné lokality typu řemeslnického předměstí. Přestože se na některých městištích snad již od konce první poloviny 14. století začínaly součástí starší stavební osnovy

7 Detailní informace k topografii levobřežního předměstí a jeho archeologickému výzkumu včetně terénních sondáži předcházejících systematickému odkryvu Archeologického ústavu AV ČR Praha, v. v. i., a Husitského muzea v Táboře (tj. před 60. lety 20. století) jsou obsaženy in Richter-Krajíc 2001.

8 Podrobněji k rozsahu osídlení a charakteru jeho zástavby ve 13. století viz Richter-Krajíc 2001, 121-124, 149. 


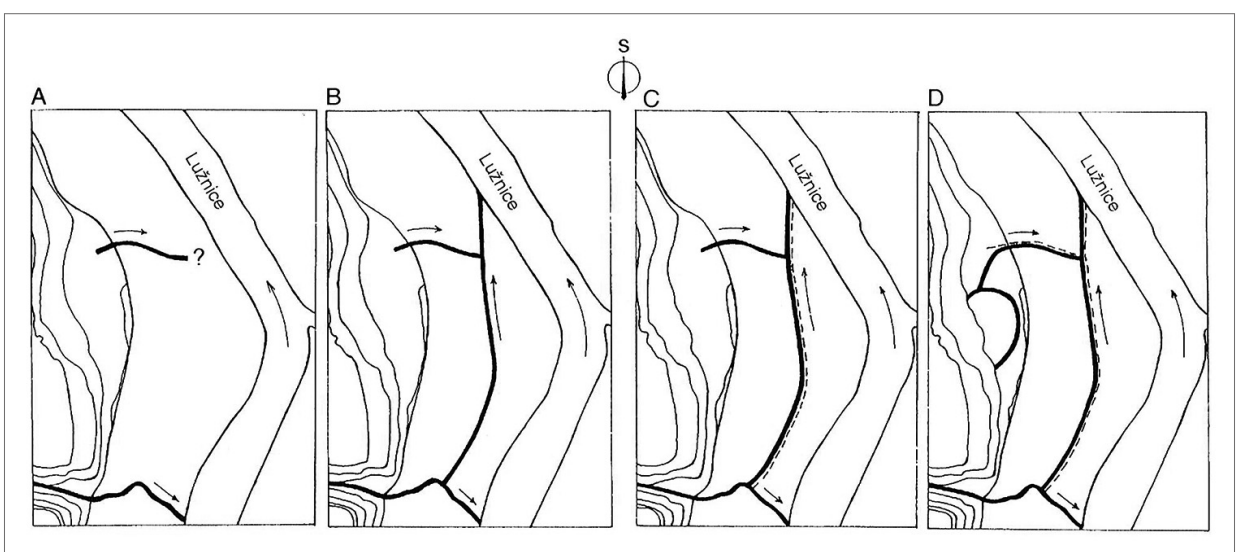

Obr. 6. Zdroje vody na ústeckém levobřežním předměstí od 13. do počátku 15. století. A - situace před osídlením ve 13. století - na východě Lužnice, na západě svah, na jihu tzv. Pracovský potok, na severu obdobně směrovaný potok, přírodní zdroj vody; B - situace ve 13. století po osídlení lužnického levobřeží - v rámci sídliště byly využity všechny shora uvedené vodní zdroje a navíc byla ve směru sever-jih vybudována vodoteč probíhající od Pracovského potoka k potoku severnímu a vtékající za ním do Lužnice; $\mathrm{C}$ - situace v první polovině 14 . století - podobná jako v předchozím období, avšak severojižní potok byl zdokonalen vybudováním nového koryta, vzdáleného jen několik metrů západně od staršího (v tomto období již zaniklého čárkovaně); D - situace ve druhé polovině 14 . století až do zániku lokality v roce 1420 - zaniklo starší koryto severního potoka (čárkovaně) a o několik metrů jižněji byla vybudována umělá vodoteč, vytékající z nejspodnější nádrže nově vybudované soustavy zásobníkủ vody v západním svahu. Podle Richter-Krajíc 2001, 132, obr. 170.

Abb. 6. Wasserquellen in der linksufrigen Vorstadt von Ústí ab dem 13. bis Anfang 15. Jahrhundert. A - Situation vor der Besiedelung im 13. Jahrhundert - im Osten die Lainsitz, im Westen ein Hang, im Süden der sog. Bach Pracovský potok, im Norden ein ähnlich orientierter Bach, natürliche Wasserquelle; B - Situation im 13. Jahrhundert nach Besiedelung des linken Ufers der Lainsitz - im Rahmen der Siedlung wurden alle oben aufgeführten Wasserquellen genutzt, zusätzlich dazu wurde in Nord-Süd-Richtung vom Bach Pracovský potok aus ein Wasserlauf angelegt, der zum nördlichen Bach verlief und hinter diesem in die Lainsitz floss; $\mathrm{C}$ - Situation in der ersten Hälfte des 14. Jahrhunderts - mit der vorhergehenden Zeit vergleichbar, jedoch wurde der Nord-Süd-Bach durch den Bau eines neuen Bettes verbessert, das nur einige Meter westlich vom älteren (zu diesem Zeitpunkt bereits verschwundenen, gestrichelt dargestellten) Bettes entfernt lag; $D$ - Situation in der zweiten Hälfte des 14. Jahrhunderts bis zum Untergang der Fundstelle im Jahr 1420 - verschwundenes älteres Bett des nördlichen Baches (gestrichelt), einige Meter südlicher wurde ein künstlicher Wasserlauf angelegt, der aus dem untersten Reservoir des im Westhang neu angelegten Wasserspeichersystems herausfloss. Nach Podle Richter-Krajíc 2001, 132, Abb. 170.

stávat nové typy obytných, př́ípadně i hospodářsko-provozních objektů (Richter-Krajíc 2001, 124), je zřejmé, že i při přestavbě předměstí po polovině 14. století byly ještě zohledňovány i některé starší sídelní či výrobní tradice. Dochované terénní nálezové situace ukazují na to, že kolem poloviny a po polovině 14 . století začalo na předměstí probíhat vyspělejší strukturování celého areálu, jehož cílem bylo posílení a zdokonalení sídelně-provozních podmínek zdejších obyvatel. Patrně se nejednalo o jednorázovou akci, ale o proces, který vyvrcholil v průběhu poslední čtvrtiny 14. století. Mohlo se jednat o komunálně organizované aktivity, zaměřené především na narůstající potř̌eby zdejších řemeslníků a splňující i požadavky na odpovídající bydlení bez ohledu na nebezpečí záplav. Tato tendence je sledovatelná na severním okraji předměstí úzkou funkční a prostorovou vazbou usedlostí na nově zrrízený vodohospodářský systém s vodní nádrží u paty západního svahu a z ní uměle vedeného vodního kanálu. Koryto tohoto nového potoka vytvořilo sídelní osu severního okrsku se šesti usedlostmi, řazenými podél potoka ve směru západ-východ, přičemž došlo i k dosídlení ploch na severozápadním okraji sídliště (dvě rozlehlé parcely cihlářských hutí). Novou podobu získal postupem doby i severojižní - středem předměstí vedený - umělý potok, jehož účelem vedle př́vodu vody bylo i odvodňování staveb a ploch na terase západně od ní (kanálky pod podlahami sklepů, vyvedené k vodoteči ve svahu terasy; trativodní kanály; odvod z haltýřové jímky). V období, kdy došlo k vyhloubení koryta severojižní vodoteče (první polovina 14. století), byly podél ní situovány odděleně stojící domy, vystřídané ve druhé polovině století prostorově souvislou oboustrannou zástavbou. Z uvedeného vyplývá, že dislokace usedlostí v poslední fázi osídlení nebyla výsledkem osazení realizovaného živelně jednotlivými usedlíky a aditivního 
nárůstu městišt', ale jednotného záměru - parcelní členění připomíná situaci v městských jádrech (Richter-Krajíc 2001, 149). V důsledku shora popsaného procesu získalo ústecké levobřežní sídliště charakter řemeslnického předměstí, který si uchovalo (s minimálními úpravami) po dobu více než jedné generace, tj. od poslední čtvrtiny 14. století do roku 1420. Tehdy - spolu s městem na protějším břehu a s dalšími předměstími - zaniklo požárem.

Před zánikem se zde nacházelo asi dvacet usedlostí, z nichž bylo šestnáct archeologicky prozkoumáno (obr. 5; Richter-Krajíc 2001). Parcely jednotlivých městišt' zde dosahovaly v průčelí šířek mezi 18 a 30 m (60-90 stop) a jejich délka - a tudíž i plocha - se odlišovaly podle vzdálenosti čela od svahu nebo říčního břehu (obr. 5 a 7). Archeologickým výzkumem byla prokázána značná pestrost zástavby jednotlivých městišt', vedle přízemních domů s podsklepeným obytným jádrem hrála významnou roli výroba a jí odpovídající množství výrobních zařízení a provozních či hospodářských objektů (podrobněji k zástavbě jednotlivých usedlostí srov. Richter-Krajíc 2001). Typy domů a dalších staveb, včetně jejich uspořádání na parcelách, nedovolují považovat žádnou z prozkoumaných usedlostí ústeckého levobřežního předměstí za typické hospodářství zemědělce. Základní obživou zdejších obyvatel se stalo řemeslo. Z celkového počtu šestnácti prozkoumaných sídlištních jednotek lze u devíti určit pracovní zaměření jejich obyvatel, u dalších pěti s jistou pravděpodobností a ve zbývajících případech bude zapotřebí stávající hypotetické určení dále upřesňovat nebo se u nich nedostává př́mých dokladů o provozovaném řemesle. Většina zdejší produkce byla určena pro potřeby města a pro regionální trh. Snad jen kumulace hrnčírư (jsou doloženi i na dalších ústeckých předměstích) naznačuje širší odbyt.

Díky výjimečným okolnostem zániku a dlouhodobému neporušení středověkých reliktů zachovaných pod povrchem bylo možné v mnoha př́ípadech - zvláště pro období tzv. zánikového horizontu, tedy pro poslední sídelní etapu od konce 14 . století do roku 1420 - identifikovat

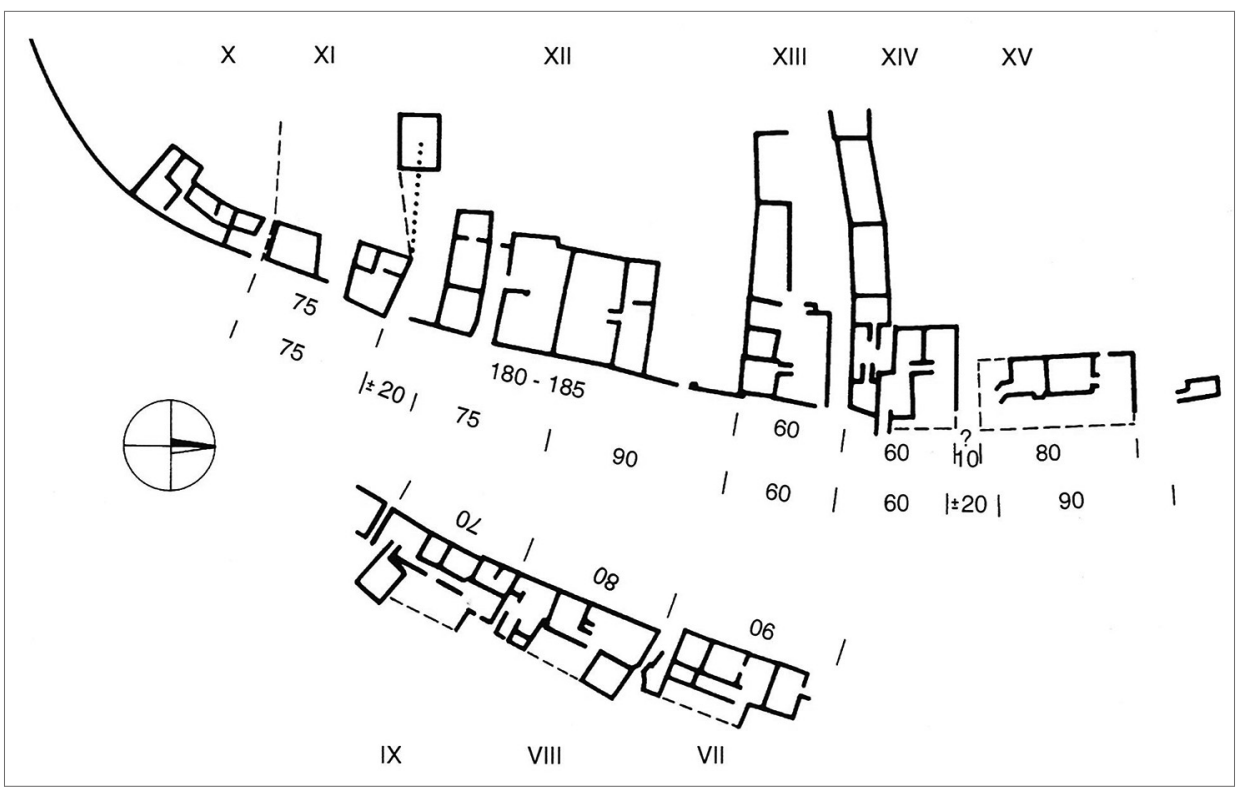

Obr. 7. Sezimovo Ústí - jižní část levobřežního předměstí na počátku 15. století s vyznačením šiřky parcel ve stopách (ca $0,3 \mathrm{~m})$. Pod nimi jsou uvedeny varianty některých parcelních šířek ve starších subetapách tzv. zánikového horizontu během rozšiřování zastavěné plochy, případně při korekturách původního rozměření. Podle Richter-Krajíc 2001, 139, obr. 177.

Abb. 7. Sezimovo Ústí - Südteil der linksufrigen Vorstadt zu Beginn des 15. Jahrhunderts mit Angabe der Parzellenbreiten in Fuß (ca. 0,3 m). Darunter werden Varianten einiger Parzellenbreiten in älteren Subetappen des sog. Untergangshorizontes während der Erweiterung der bebauten Fläche, ggf. bei Korrekturen der ursprünglichen Unterteilung angegeben. Nach Richter-Krajíc 2001, 139, Abb. 177. 
a specifikovat nejen zástavbu jednotlivých městišt', ale i určit pracovní zaměření jejich obyvatel na základě objevených výrobních a provozních zařízení a početných souborů artefaktů, které výrobu provázely (hotové a defektní výrobky, polotovary, suroviny, nástroje ad.). Z řemesel provozovaných na tomto levobřežním ústeckém předměstí se dosud podařilo identifikovat kováře, sladovníka, dvě cihlářské huti a pět hrnčířských usedlostí (Richter-Krajíc 2001).

V severozápadním rohu sídliště byly po polovině 14 . století vybudovány dvě cihlářské huti (obr. 5 - usedlosti I-II; obr. 8). Plocha větší z nich přesáhla $2000 \mathrm{~m}^{2}$. Vedle obytných domů zde byly objeveny vypalovací pece, výrobní haly a provozní místnosti, studny a značné množství hotových i defektních výrobků stavební keramiky. Surovina (hlína) na výrobu byla odebírána z přilehlého západního svahu předměstí. V ústeckých cihelnách se vyráběla tzv. zdicí a krycí keramika, tj. cihly, formovky, prejzy, háky a nezdobené dlaždice (Krajíc 2008).

$\mathrm{S}$ cihelnami sousedila přes širokou štětovanou cestu, kterou bylo možno v severozápadním rohu opustit sídliště, usedlost sladovníka s $23 \mathrm{~m}$ dlouhým celokamenným domem a bočně přilehlým dvorem (obr. 5 - usedlost III; obr. 9). V čele domu se u potoka nacházelo podsklepené obytné jádro. Další místnosti domu a stavby i prostory na zbytku parcely souvisely se zde provozovaným řemeslem. Se sladovnictvím lze spojovat nálezy hvozdu ve středním traktu domu a provozně hospodářskou místnost se špýchárkem $\mathrm{v}$ jeho týlu, zatímco humno, trativod a studna byly umístěny do dvora v těsném sousedství domu (Krajíc 1989, 159-187).

Na opačný konec severního předměstského okrsku, tj. do severovýchodního rohu předměstí, byla situována kovárna (obr. 5 - usedlost VI; obr. 10). Její zástavbu tvořil dvoutraktový celokamenný dům zahrnující obytnou část, kovárnu s výhní a několik provozně-hospodářských místností. $\mathrm{K}$ domu přiléhal dvůr. Na ploše parcely bylo nalezeno přes $700 \mathrm{~kg}$ kovářských strusek, pracovní nářadí, hotové železné výrobky, polotovary, předměty určené na překování ad. (Krajíc 1993a,

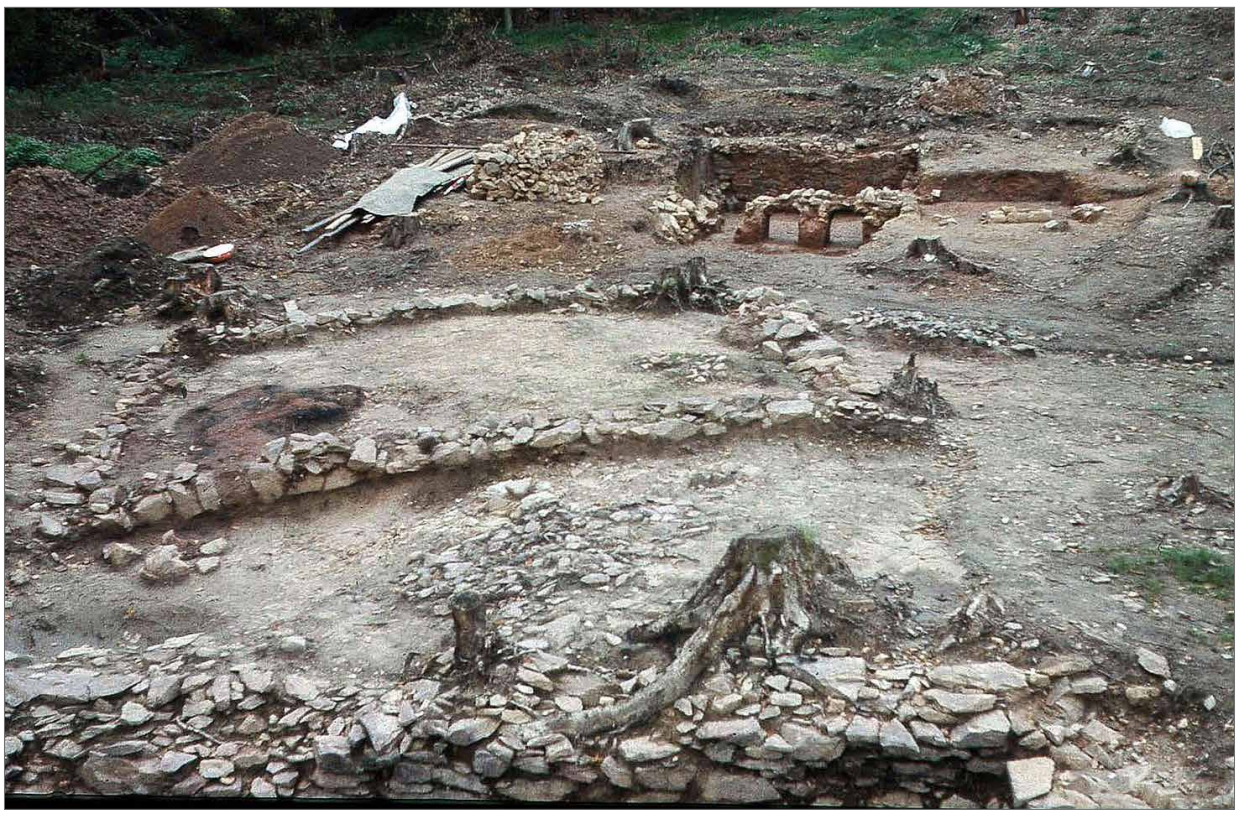

Obr. 8. Sezimovo Ústí - levobřežní předměstí, usedlost II. Relikty části zástavby druhé cihlářské huti z období tzv. zánikového horizontu lokality. $V$ popředí pozủstatky trojdílného domu (podsklepená část u spodního okraje), v pozadí torza dvou vypalovacích pecí. Podle Krajíc 2008.

Abb. 8. Sezimovo Ústí - linksufrige Vorstadt, Anwesen II. Relikte eines Teils der Bebauung der zweiten Ziegelhütte aus der Zeit des sog. Untergangshorizontes der Fundstelle. Im Vordergrund die Überreste eines dreiteiligen Hauses (unterkellerter Teil am unteren Rand), im Hintergrund die Torsi zweier Brennöfen. Nach Krajíc 2008. 


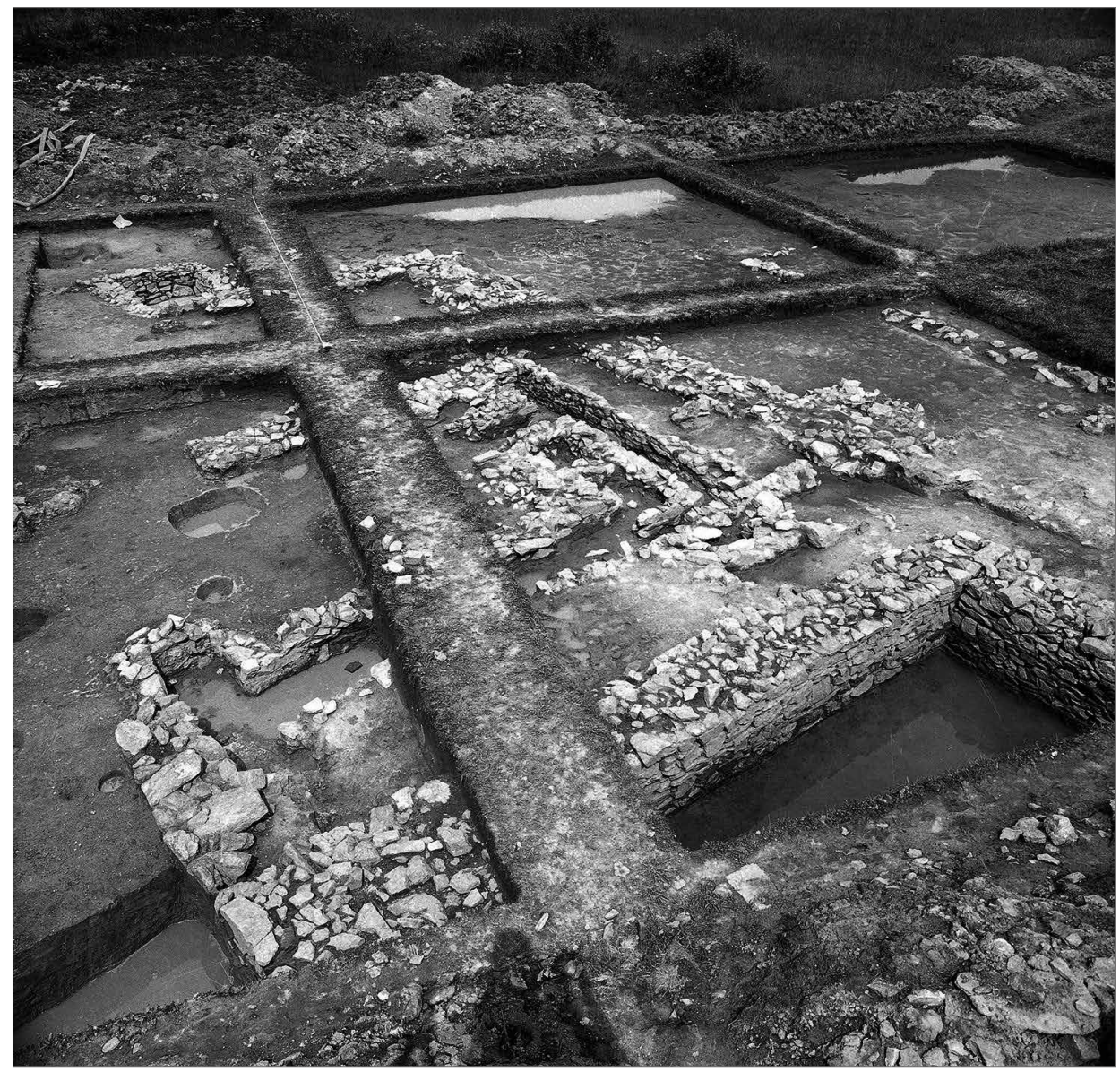

Obr. 9. Sezimovo Ústí - levobřežní předměstí, usedlost III. Relikty domu sladovníka z období tzv. zánikového horizontu lokality. $\mathrm{V}$ popředí (dole) část odkrytého sklepa v čele domu, ve stř̌edu hvozd, v pozadí hospodářsko-provozní místnost s napojeným sklípkem. Podle Krajíc 1989, 159-187.

Abb. 9. Sezimovo Ústí - linksufrige Vorstadt, Anwesen III. Relikte des Hauses eines Mälzers aus der Zeit des sog. Untergangshorizontes der Fundstelle. Im Vordergrund (unten) Teil des freigelegten Kellers an der Front des Hauses, in der Mitte eine Malzdarre, im Hintergrund ein Wirtschafts-Betriebs-Raum mit Getränkekeller. Nach Krajíc 1989, $159-187$.

391-417). Díky nálezu této ústecké předměstské kovárny bylo následně samostatně zpracováno téma středověkého kovářského řemesla na př́íkladu analyzovaných 18000 železných předmětů ze zaniklého Ústí (Krajíc 2003).

Na březích severojižního potoka se nacházelo pět hrnčířských usedlostí (obr. 5 - usedlosti VIII, IX, X, XII a XIII). Vedle obytných jader domů byly zbývající části parcel využívány téměř výlučně ke zde provozovanému řemeslu. Na městištích se tak nacházely výrobní haly, sklady surovin, vypalovací jednoprostorové kupolovité pece, vysoušecí prostory s kanálovitými topeništi, obvykle větší počet studní a značné množství hotových výrobků, odpadů, pracovních pomůcek ad. (Richter 1978; 1993, 44-51; Richter-Krajíc 2001). V ústeckých hrnčířských dílnách se vyráběla vedle užitkové i kamnářská keramika (Hazlbauer-Richter 1990, 416-434, 462-472; Hazlbauer-Chotěbor 1991, 361-383).

Přestože je u zbývajících usedlostí na levobřežním předměstí zatím obtížné vyvodit $\mathrm{z}$ dochovaných reliktů a výbavy usedlostí přesné pracovní zaměření jejich obyvatel, nelze vyloučit, 


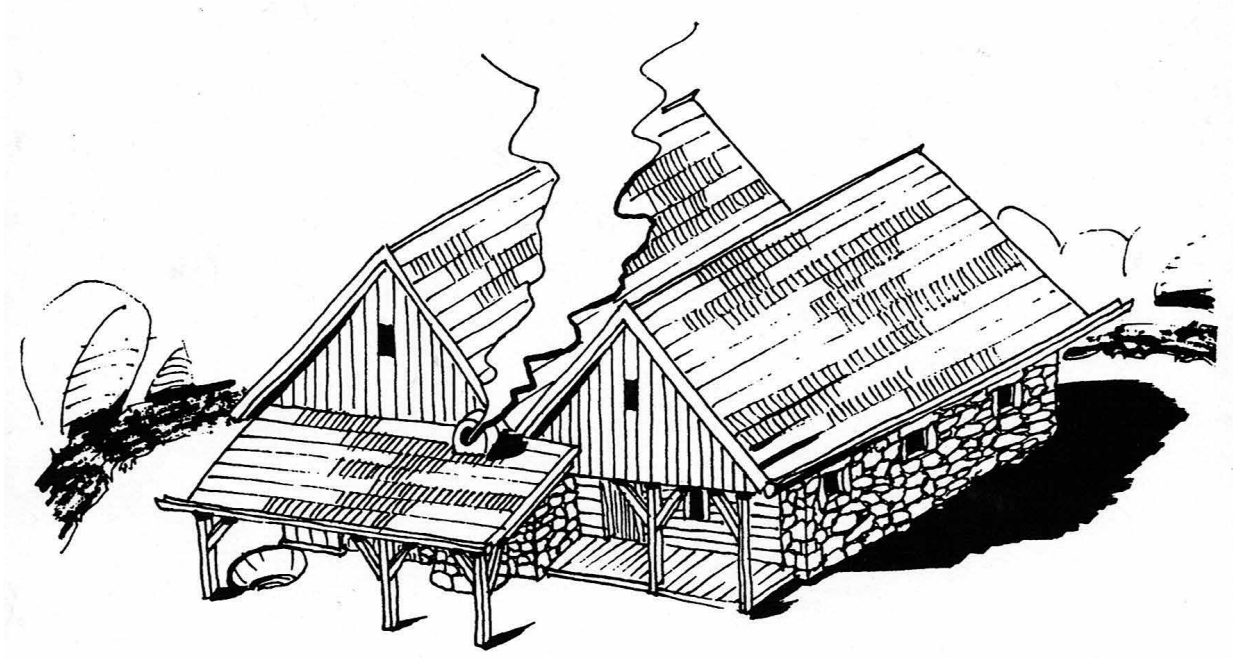

Obr. 10. Sezimovo Ústí - levobřežní předměstí, usedlost VI. Kresebná rekonstrukce podoby předměstské kovárny v období tzv. zánikového horizontu lokality. Podle návrhu R. Krajíce a M. Roháčka in Krajíc 2003.

Abb. 10. Sezimovo Ústí - linksufrige Vorstadt, Anwesen VI. Zeichenrekonstruktion des Aussehens der Vorstadtschmiede zur Zeit des sog. Untergangshorizontes der Fundstelle. Nach dem Entwurf von R. Krajíc und M. Roháček in Krajíc 2003.

že by některé z nich mohly ukazovat na pracoviště pekaře, řezníka, koželuha či řemeslníků zabývajících se textilní a kožedělnou výrobou (Richter-Krajíc 2001).

\section{Shrnutí poznatků}

Jihočeské Sezimovo Ústí reprezentuje typ středověkého poddanského města řemeslnicko-zemědělského charakteru, jež bylo postupem doby obklopeno třemi předměstími. Jejich vývoj a sídelně-provozní poměry bezprostředně souvisely se zájmy a potřebami města. Zatímco jedno z předměstí (levobřežní) nabylo během času podoby výrobní příměstské oblasti, ostatní články ústecké aglomerace se více zaměřily na zásobování městského trhu potřebnými produkty a na služby. V případě severovýchodního předměstí nelze vyloučit specifické okolnosti jeho vzniku. Podnět k jeho založení mohl být dán jednorázovým př́íchodem většího počtu obyvatel z nedalekého Hradiště (z táborského ostrohu, dnešního historického centra Tábora) na konci 13. století.

\section{Literatura}

BAČOVÁ, V., 2010: Nálezy ze Sezimova Ústí (okr. Tábor) ve sbírce J. A. Jíry, Archaeologia Pragensia 20, 422-435.

BERÁNEK, K., 1998: Dvě listiny z Ústí nad Lužnicí ve Státním ústředním archivu v Praze, Táborský archiv 8/1997-1998, 5-10.

BŘICHÁČEK, P.-ŠINDELÁŘ, J., 2018: Nové poznatky o zaniklém konventu dominikánů v Sezimově Ústí (okr. Tábor), AZČ 9, 66-74.

CIKHART, R., 1951: Minulost Sezimova Ústí, JSH XX, 7-14, 87-93, 128-133.

ČERVENKA, V., 1938: Sezimovo Ústí v minulosti a př́itomnosti s plánem a 4 obrázky. Sezimovo Ústí.

DENKSTEIN, V., 1951: O archeologický výzkum husitských lokalit, ČNM CXX, 107-115. 
DRDA, M.-KRAJÍC, R., 2001: Tzv. Husův hrneček - originál nebo dokonalý padělek?, Husitský Tábor Supplementum 1, 505-601.

DRDA, M.-TECL, R., 1978: K předhusitskému osídlení Tábora, ČsČH 26, 740-764.

HAZLBAUER, Z.-RICHTER, M., 1990: Dva hromadné nálezy gotických nádobkových kachlů v Sezimově Ústí, AR XLII, 416-434, 462-472.

HAZLBAUER, Z.-CHOTĚBOR, P., 1991: Stavební rekonstrukce dvou vrcholně gotických kamen ze Sezimova Ústí - Ensembles hochmittelalterlicher Töpferkacheln aus Sezimovo Ústí, AH 15, 361-383.

HRDLIČKA, L.-RICHTER, M.-SMETÁNKA, Z., 1966: Výzkum v Sezimově Ústí v r. 1965, AR XVIII, $663-680$.

HUML, V., 1965: Sezimovo Ústí - záchranný výzkum 1965. NZ AÚ ČSAV Praha, čj. 5880.

- 1966: Záchranný výzkum v Sezimově Ústí (okr. Tábor) v r. 1965, AR XVIII, 344-45.

KOLÁŘ, M., 1924: Dějiny Ústí Sezimova a začátky Tábora, Sborník historických prací prof. Martina Koláře o dějinách Tábora, 34-68.

KOŘALKA, J., 1996: Nálezy ze Sezimova Ústí v soukromé sbírce Josefa Pachla z první poloviny 19. století, Táborský archiv. Sborník Státního okresního archivu v Táboře 7, 219-232.

KOVÁŘ, M., 2017: Marginálie k diskusi o počátcích dominikánského kláštera v Sezimově Ústí, ČSPS 125 , 145-158.

KRAJÍC, R., 1982: Výzkum středověké keramické pece v Táboře, AR XXXIV, 269-277.

- 1989: Středověká sladovna v Sezimově Ústí, PA LXXX, 159-187.

- 1991: Stavební železo a uzavírací mechanizmy na vrcholně středověkých lokalitách Táborska - eiserne Baubeschläge und Verschließungsmechanismen von den hochmittelalterlichen Lokalitäten in der Gegend von Tábor, AH 16, 323-342.

- 1993: Die Handwerkervorstadt von Sezimovo Ústí (Teil II). In: Archäologische Arbeitsgemeinschaft Ostbayern/West- und Südböhmen. Resümees der Vorträge, 51-56. Deggendorf - Tabor.

- 1993a: Středověká kovárna v Sezimově Ústí - Novém Městě - Eine Schmiedewerkstatt in Sezimovo Ústí-Neustadt, AH 18, 391-417.

- 1995: Sezimovo Ústí - Bydlinského ulice. NZ HM Tábor, př. č. 36.

- 1996: Příspěvek k opevnění a zástavbě středověkého Sezimova Ústí (Archeologický výzkum v Bydlinského ulici v 1. 1990-1991), AVJČ 9, 76-136.

- 1998: Sezimovo Ústí I. NZ HM Tábor, př. č. 46.

- 2003: Sezimovo Ústí. Archeologie středověkého poddanského města 3. Kovárna v Sezimově Ústí a analýza výrobků ze železa. Díl I-II. Praha - Sezimovo Ústí - Tábor.

- 2004: Archeologický výzkum na stavbě Tábor - obchodní centrum BAUMAX. Sml. 3/2004. NZ HM Tábor, př. č. 83 .

- 2005: Výroba keramické střešní krytiny ve středověkém Sezimově Ústí, Svorník 3, 257-268.

- 2007: Sezimovo Ústí I - Švehlova ul. ppč. 523/1. Zpráva o archeologickém výzkumu, HM Tábor.

-2007-2008: Archeologický výzkum na stavbě Tábor - obchodní centrum AVENTIN. Sml.15/2007. NZ HM Tábor, př. č.166 a 169.

- 2008: Středověké cihlářství. Sezimovo Ústí - archeologie středověkého poddanského města 4. Praha - Sezimovo Ústí - Tábor.

- 2008a: Archeologický výzkum v Sezimově Ústí v r. 2007. In: Ve službách archeologie 2, 76-81. Brno.

- 2009: Sezimovo Ústí - Švehlova ulice čp. 66. NZ HM Tábor, př. č. 183.

- 2010: Sezimovo Ústí I - Švehlova ulice čp. 66. Archeologický výzkum v historickém centru města v roce 2009, AVJČ 23, 273-282.

KRAJÍC, R.-RICHTER, M., rkp.: Sezimovo Ústí - archeologie středověkého poddanského města I. Topografie a dějiny bádání. Rukopis.

MÁŠKA, F., 1946: Zř́íceniny bývalého Sezimova Ústí a kláštera, obraz bývalého města. Rukopis.

OPRAVIL, E., 1972: Synantropní rostliny ze středověkého Sezimova Ústí, Presliana, 37-46.

PPFL: Písemná pozůstalost Františka Lískovce. Husitské muzeum Tábor.

REICHERTOVÁ, K., 1965: Středověká keramika ze Sezimova Ústí, Tábora a Kozího Hrádku. ASM III. Praha. RICHTER, M., 1967: Některé výsledky a problémy výzkumu v Sezimově Ústí, AR XIX, 712-717. 
- 1969: Výzkum v Sezimově Ústí v 1. 1966-1968, AR XXI, 768-782.

- 1974: Der archäologische Beitrag zur Kleinstadtforschung in Böhmen, Vor- und Frühformen der europäischen Stadt im Mittelalter II, 239-257.

- 1975: České středověké město ve světle archeologických výzkumů, AR XXVII, 245-258.

- 1978: Středověká keramika ze Sezimova Ústí. České Budějovice.

- 1986: Sezimovo Ústí. A part of the project of investigations of Bohemian urban settlements. In: Archaeology in Bohemia 1981-1985, 229-236. Praha.

- 1993: Die Handwerkervorstadt von Sezimovo Ústí (Teil I), Archäologische Arbeitsgemeinschaft Ostbayern/West- und Südböhmen 2, 44-51. Deggendorf- Tabor.

- 1994: Sezimovo Ústí. In: 25 Years of Archaeological Research in Bohemia. PA - Supplementum I, 201-206. Praha.

RICHTER, M.-DRDA, M., 1981: Sezimovo Ústí (Alttabor) und Tabor. Ergebnisse archäologischer Forschungsgrabungen in Südböhmen, Mitteilungen des Instituts für österreichische Geschichtsforschung LXXXIX, 1-21.

RICHTER, M.-HRDLIČKA, L., 1965: Výzkum v Sezimově Ústí v roce 1964, AR XVII, 647, 655-668.

RICHTER, M.-KRAJÍC, R., 2001: Sezimovo Ústí. Archeologie středověkého poddanského města 2. Levobřežní předměstí - archeologický výzkum 1962-1988. Praha.

RICHTER, M.-SMETÁNKA, Z.-ŠPAČEK, L., 1964: Výzkum v Sezimově Ústí v r. 1962 a 1963, AR XVI, 691-715.

SEDLÁČEK, A., 1933: Hrady, zámky a tvrze království Českého IV. Praha.

ŠMAHEL, F. a kol., 1988: Dějiny Tábora. I. díl, 1. svazek. Do roku 1421. České Budějovice.

ŠNOBLOVÁ, M., 2011: Dominikánské konventy v Čechách zaniklé v době husitské. Bakalářská práce, Katedra dějin a didaktiky dějepisu, Pedagogická fakulta, Univerzita Karlova.

ŠVEHLA, J., 1900: Z českých Pompejí. Tábor.

- 1901: Nádobí kuchyně a stolu staročeského. Tábor.

- 1907: Ústí Sezimovo. Knihovnička Jiskry.

- 1913: Ústské dlaždice. Zvl. otisk z XVIII. výroční zprávy městského muzea v Táboře za rok 1913, 1-15. Tábor.

- 1915: Ústí Sazemino, Jihočeský kraj V, 396-400.

- 1928: Ohlasy z Ústí Sezimova v nejstarší gruntovní knize táborské z r. 1432-1450, JSH I, 80-84, 120-124.

- 1929: Ústí Sezimovo. In: Tábor město Žižkovo. Tábor.

- 1930: Několik vzpomínek na dominikánský klášter v Ústí Sezimově, JSH III, 1-9.

- 1930a: Farní kostel a fara v Ústí Sezimově, JSH III, 87-91.

- 1931: Špitál v Ústí Sezimově, JSH IV, 123-124.

\section{Zusammenfassung}

\section{Die mittelalterliche Stadtwüstung Sezimovo Ústí}

Sezimovo Ústí liegt in Südböhmen in der Nähe von Tabor. Ihre mittelalterliche Geschichte ist unmittelbar mit den Anfängen des Hussitentums verbunden. Die Stadt Ústí wurde um Mitte des 13. Jahrhunderts von Witigonen, wahrscheinlich von den Herren von Hradec, am Zusammenfluss der Lainsitz und des Baches Kozský potok gegründet. Dabei handelte es sich um eine Aktivität, die mit der mittelalterlichen Urbanisierung in südböhmischen Grundherrschaften des Adels zusammenhing. Nicht lange nach der Gründung von Ústí war die Entwicklung der Gemeinde durch den Bau einer neuen Stadtsiedlung auf dem nahegelegenen Taborschen Felsenplateau bedroht, deren Initiator Přemysl Ottokar II. war. Eine der Absichten für die Stadtgründung auf dem Felsenplateau sei das Bestreben des Herrschers gewesen, die zunehmende Macht der Witigonen in Südböhmen einzudämmen. Dieser Versuch, einen neuen Stützpunkt an der strategisch günstigen Lage an der Lainsitz zu gründen, blieb nach dem Tod des Herrschers jedoch unerfüllt. Die nahegelegene 
Stadt Ústi konnte sich so ohne deutlichere Konkurrenz in seiner nächsten Umgebung zu einem regionalen Zentrum entwickeln (Richter-Krajíc 2001).

Während ihrer über hundertfünfzigjährigen Geschichte erhielt Ústí das Aussehen einer hochmittelalterlichen Untertanenstadt mit Befestigungsanlage, einem Pfarramt, einer Pfarrkirche an der höchsten Stelle des Stadtkerns, einem Kloster und ansehnlichen Bürgerhäusern um den rechteckigen Marktplatz. Das umfriedete Stadtareal nahm eine Fläche von ungefähr 10 ha ein. Die Stadt wurde am rechten Ufer der Lainsitz im Bereich des heutigen Stadtteils Sezimovo Ústí I errichtet und nach und nach von drei Vorstädten umgeben.

Anfänglich war die Stadt nur von einer einfachen Befestigungsanlage umfriedet. Der rechteckige Grundriss der Stadt wurde an der nordwestlichen Seite um einen relativ ausgedehnten dreieckigförmigen Ausläufer erweitert, der für das Areal eines Dominikanerklosters ausgegliedert wurde. Eine vorerst ungeklärte Frage bzgl. der Anfangszeit und des daran anschließenden Zeitraums bleibt die Lage und das Aussehen des Sitzes der Stadteigentümer, die ab Ende des 13. Jahrhunderts als Herren von Auzt (Ústí) angegeben werden. Bereits während des 14. Jahrhunderts war Ústí eine Stadt mit handwerklich-landwirtschaftlichem Charakter. Die Produktion richtete sich überwiegend auf den lokalen Markt. Die Stadt profitierte nicht nur von der aufblühenden Handwerksproduktion, sondern auch von der günstigen Lage, die dem Transithandel von Prag ins Donaugebiet entgegenkam. Ende des 13. oder Anfang des 14. Jahrhunderts war die Stadt besser befestigt, und zwar mit einer Stadtmauer und einer Bastion in der nordöstlichen Ecke. Ende des 14. Jahrhunderts wurde in Ústí (wahrscheinlich in der Vorstadt) ein Spital gegründet (Richter-Krajíc 2001).

Mit fortschreitender Zeit wurde Ústí von drei Vorstädten umgeben, die der Stadt ein willkommenes wirtschaftlich-betriebliches Hinterland schuf und für die wachsende Einwohnerzahl Lebensraum bot. Die erste dieser Vorstädte war eine selbständig befestigte drei Hektar große Fläche, die an den nordöstlichen Stadtrand anschloss. An der Südseite der Gemeinde befand sich um den Bach Kozský potok die zweite Vorstadt mit einer Anlegestelle. Die dritte Vorstadt wurde hinter dem Fluss am linken Ufer der Lainsitz angelegt. Im Unterschied zu den vorhergehenden zwei, bei denen archäologische Freilegungen nur in begrenztem Maße durchgeführt werden konnten, wurde in der linksufrigen Vorstadt in den Jahren 1962-1988 eine Geländegrabung durchgeführt, die sich im Laufe der Jahre von einer Rettungsgrabung zu der flächenmäßig ausgedehntesten archäologischen Grabung einer mittelalterlichen Vorstadt in Tschechien entwickelte. Dank dessen lässt sich diese Vorstadt auch detaillierter charakterisieren (Richter-Krajíc 2001). Auf der untersuchten Fläche wurden die Überreste einer Siedlung freigelegt, deren mittelalterlichen Anfänge in das 13. Jahrhundert fallen. Im Laufe des 14. Jahrhudnerts hatte sie bereits den Charakter einer handwerklichen Vorstadt. Diese ging (ebenso wie die Stadt am gegenüberliegenden Ufer) im Jahre 1420 durch einen Brand unter. Eine Rekonstruktion des ursprünglichen Aussehens der Siedlung - die in ihrer endgültigen Form ca. 20 handwerkliche Anwesen umfasste (von denen 16 archäologisch untersucht wurden) - und des Lebens in ihr war nicht nur wegen den entdeckten Relikten von Häusern, Wirtschaftsbauten und Produktionseinrichtungen möglich, sondern auch wegen den zehntausenden Gegenständen, die zur Ausstattung von Haushalten, Werkstätten u.ä. gehörten. Von den dort betriebenen Gewerben konnten bisher die Anwesen eines Schmiedes, eines Mälzers, zwei Ziegelhütten, fünf Töpferhäuser u.a. identifiziert werden. (Richter-Krajíc 2001; Krajíc 1989, 159-187; 2003; 2008).

Der Untergang der mittelalterlichen Stadt Ústí hängt unmittelbar mit den Anfängen der Hussitenbewegung in Südböhmen zusammen. In Ústí und seiner Umgebung hat sich Magister Jan Hus aufgehalten, dessen Gedankengut von den Anhängern der Reformbewegung dort auch nach dessen Tod verbreitet wurde. Infolge der wachsenden Spannungen wurde Ústí Ende Februar 1420 von den Hussiten eingenommen und besetzt. Da die Stadt aus militärisch-strategischer Sicht keine allzu günstige Lage hatte, entschieden sich die Hussiten dazu, auf das nahegelegene Felsenplateau oberhalb der Lainsitz und des Baches Tismenický potok überzusiedeln, wo sie eine Burgberg Tabor genannte Hussitengemeinde gründeten. Damit das in unmittelbarer Reichweite 
gelegene Ústí zu keinem gefährlichen Stützpunkt der Feinde werden konnte, wurde es am 30. März 1420 niedergebrannt. Die Bevölkerung ist - falls sie die Stadt zuvor nicht schon selbst verlassen hatte - in die nahegelegene neugegründete Gemeinde auf dem Taborschen Felsenplateau gezogen oder wurde dorthin umgesiedelt (detaillierter siehe Richter-Krajíc 2001).

Nach dem Untergang blieb die Fläche der Stadt bis zum Beginn des 19. Jahrhunderts unbesiedelt. Im Jahr 1828 wurde dort die Siedlung Alt Tabor gegründet, die im Jahr 1920 in Sezimovo Ústí umbenannt wurde.

prof. PhDr. Rudolf Krajíc, CSc., Archeologický ústav Filozofické fakulty Jihočeské univerzity v Českých Budějovicích, Branišovská 31a, 37005 České Budějovice, Česká republika, krajic@ff.jcu.cz 
